\title{
МЕДСЕСТРИНСЬКИЙ ФАКТОР У ЗАСВОЄННІ АЛГОРИТМУ САМООБСТЕЖЕННЯ МОЛОЧНОЇ ЗАЛОЗИ
}

\author{
С. О. Платовська, Л. М. Маланчук \\ ДВНЗ «Тернопільський державний медичний університет \\ імені I. Я. Горбачевського МОЗ України"
}

\begin{abstract}
У статті висвітлено роль медсестри в профілактиці раку молочної залози. Акцентовано увагу на процесі навчання як середнього медичного персоналу, так і пацієнток.
\end{abstract}

\section{NURSING FACTOR IN THE LEARNING ALGORITHM OF BREAST SELF-EXAMINATION}

\author{
S. O. Platovska, L. M. Malanchuk \\ SHEI «Ternopil State Medical University by I. Ya. Horbachevsky of MPH of Ukraine» \\ The article is devoted to the role of nurses in the prevention of breast cancer. The focus is on the \\ process of learning born on nursing staff and patients.
}

Вступ. Рак молочно залози (РМЗ) займає перше місце в структурі жіночо онкопатологі як в Укра ні, так і у світі. Щорічно в нашій кра ні діагностують більше 15000 нових випадків цього захворювання [1, 2]. Серед жінок, які померли від РМЗ, 30 \% складають пацієнтки репродуктивного віку. Тому питання профілактики ціє патологі таке актуальне. Статистика свідчить, що раннє виявлення та адекватне лікування дисгормональних захворювань молочно залози в 2-3 рази може зменшити злоякісну патологію цього органа [3, 4].

На сьогодні впроваджено низку ефективних програм ранньо діагностики РМЗ:

- самообстеження;

- профогляди;

- скринінгові обстеження (УЗД, мамографія, онкомаркери).

Саме в такій послідовності слід впроваджувати ці методи, оскільки проведені дослідження довели, що у 80-90\% випадків захворювання молочно залози виявляють хворі, 15-18\% випадків - під час профоглядів і лише 4-6\% під час скринінгових обстежень [2-4].

Основна частина. В системі профілактики РМЗ самообстеження $є$ одним 3 основних методів своєчасного виявлення патологі молоч-

(c) С. О. Платовська, Л. М. Маланчук, 2015 но залози. Проте на перший погляд простий і ефективний метод вимагає чітко організаційно системи в підготовці та навчанні як медичного персоналу, так і жінок [2].

Саме медична сестра, враховуючи специфіку роботи, повинна не лише надати повну інформацію, але й навчити кожну жінку правил самообстеження молочно залози. В цьому складному процесі велике значення буде мати знання медсестри з ціє проблеми, вміння ефективно використовувати вербальні і невербальні методи спілкування з пацієнткою. Такий запит сьогодення вимагає постійного самовдосконалення медперсоналу із використанням різноманітних джерел інформаці .

Будь-яка методика включає два основні прийоми: огляд та пальпацію.

І прийом - огляд:

- молочно залози;

- сосків;

- навколососково ділянки;

- ділянки периферичних лімфатичних вузлів.

Огляд необхідно проводити у теплій кімнаті, достатньо освітленій, перед дзеркалом, у вертикальному положенні в прямій і боковій проекці , з піднятими вгору і опущеними донизу руками. Спочатку треба оглянути білизну в проекці молочних залоз. Забруднення (кров'янистого, коричневого чи жовтого кольору) можуть свідчи- 
ти про виділення з сосків. Під час огляду молочних залоз потрібно звертати увагу на розташування, симетрію, розміри, форму, деформаці і шкіру особливо у вигляді «лимонно кірки».

При обстеженні сосків та навколососково ареоли зауважується х форма, забарвлення, виділення, наявність дефектів (ерозій, травм), пухлиноподібних утворів.

Збільшені периферичні вузли можуть виявлятися навіть при огляді ділянок типового $x$ розташування. Інколи під час огляду діагностуються додаткові молочні часточки.

\section{II прийом - пальпація.}

Пальпацію молочних залоз потрібно проводити в горизонтальному положенні. Для полегшення обстеження під лопатку можна покласти подушку, щоб грудна клітка, з розпластаною на ній молочною залозою, була піднята. Ліва молочна залоза обстежується правою рукою і навпаки. При цьому необхідно дотримуватися послідовності (за ходом чи проти годинниково стрілки) обстежувати всі ділянки молочно залози. Пальпація розпочинається з ділянки соска круговими рухами з центру до перифері i плавно переходить у пахвинну ділянку ціє ж сторони для визначення стану периферичних лімфатичних вузлів.

Під час прийому необхідно використовувати різні позиці : рука з того боку, що пальпується, витягнута догори, потім убік і вниз. Внутрішній бік молочно залози зручніше пальпувати 3 піднятою рукою.

Пальпація проводиться за допомогою внутрішніх поверхонь кінцевих фаланг від 2-го до 5-го пальців. Потрібно уникати охоплення велико ділянки тканини молочно залози, оскільки це може призвести до помилкового враження наявності ущільнення. При цьому потрібно уникати грубо пальпаці органа.

При обстеженні молочно залози звертається увага на наявність ущільнень, тяжів, вузлів, болючих і малорухомих ділянок. Пацієнтка повинна пам'ятати, що при виявленні відхилень від норми й необхідно негайно звернутися до лікаря на консультацію.

Ділянка обстежень периферичних лімфатичних вузлів включає не лише пахвинні, але й надключичні та шийні. Завершується пальпація молочно залози стискуванням між пальцями соска в межах ареоли. Ця метода дозволяє виявити патологічні виділення - не тільки х характер, але й кількість.

Окрім техніки обстеження молочно залози, під час навчання пацієнток потрібно звертати особливу увагу на систематичність проведення дано процедури (1 раз на місяць). Необхідно наголосити, що ці прийоми краще проводити в першу фазу менструального циклу після закінчення менструаці. В цей період молочні залози, як правило, м'які і це полегшує х огляд. Для жінок менопаузального періоду або ж з нерегулярними місячними слід рекомендувати проводити самообстеження у визначені дні кожного місяця. Під час бесіди з жінкою медична сестра рекомендує завести «календар самообстеження», до якого пацієнтка буде вносити усю інформацію, і це полегшить спостереження в динаміці та забезпечить раннє виявлення патологі.

Санітарно-просвітницька робота має на меті пропаганду здорового способу життя. В цьому сенсі самообстеження молочно залози не має на меті виявити пухлину, а насамперед $\epsilon$ адекватним методом діагностики стану здоров'я, зокрема молочно залози. Про це дуже важливо пам'ятати, оскільки страх виявлення захворювання і психологічний настрій при цьому викликають тривожність та напруженість, а така природна реакція призводить до відмови від самооглядів. Пацієнтка повинна усвідомити, що регулярне самообстеження молочно залози проводиться не з метою діагностики пухлини, а для того, щоб впевнитись у власному здоров'.

Особлива роль середніх медичних працівників у профілактиці раку молочно залози пов'язана насамперед 3 х постійним контактом із пацієнтками у різних сферах та рівнях медично допомоги. Одним з найважливіших завдань медсестри 6 мотивація жінок уважно ставитись до себе і свого здоров'я. У цьому м будуть допомагати різні медіа-засоби: радіо, телебачення, преса. Для навчання жінок широко потрібно використовувати наочну агітацію у вигляді інформаційних листів санітарно-просвітницьких бюлетенів, таблиць тощо. Усі ці матеріали повинні бути доступні не лише в таких закладах охорони здоров'я, як жіночі консультаці, пологові будинки, гінекологічні відділення, санаторі, але i в роздягальнях та душових кімнатах, фітнес-центрах та різних спортивних клубах, у ванних кімнатах готелів і под.

Не можна перебільшити роль медично сестри в організаці та проведенні цілеспрямованих профілактичних оглядах особливо серед контингенту населення з групи ризику онкопатологі . I тут мова йде не лише про рак молочно залози. Щодо проблеми РМЗ, то на сьогодні відомі фактори ризику цього захворювання. Групи високого ризику становлять насамперед особи з поєднанням певних генетичних та фенотипічних Факторів. Фактори, які підвищують ризик захворювання на рак молочно залози, такі:

- вік (понад 40 років); 
- спадкова і сімейна схильність (жінки, у яких матері або сестри хворіли на рак молочно залози, мають значно вищі шанси захворіти на ту ж хворобу);

- пізня менопауза;

- ранній початок менструацій (до 12 років);

- народження першо дитини у віці понад 30 років;

- переривання вагітності;

- жінки, які ніколи не народжували;

- фіброзно-кістозна мастопатія та інші проліферативні захворювання молочних залоз;

- ожиріння (понад 40 \% нормально маси);

- цукровий діабет, гіпертонічна хвороба;

\section{ЛITEРАТУРА}

1. Литвиненко А. А. Рак грудной железы: лечение, реабилитация и первые шаги в прогнозировании рисков / А. А. Литвиненко / / Здоровье женщины. - 2013. № 8. - C. 173-177.

2. Семиглазов В. Ф. Скрининг рака молочной железы / В. Ф. Семиглазов, В. В. Семиглазов / / Практическая онкология. - 2010. - № 11 (2). - С. 60-65.
- систематичне куріння та зловживання алкоголем.

Таким чином, ефективна профілактика раку молочно залози тісно пов'язана з рівнем освіти медично сестри та постійним бажанням до самовдосконалення.

Висновок. Сестринський процес - ретельно виважена інтелектуальна діяльність, за допомогою яко практика сестринства реалізується впорядковано та систематизовано. Роль медично сестри в процесі діагностики та профілактики захворювань МЗ складно переоцінити.

3. Скринінг, профілактика та рання діагностика раку грудної залози / С. Ю. Скляр, І.І.Смоланка, Т. С. Головко, О.В.Ганіч / / Клиническая онкология. 2013. - № 4 (12).

4. Рак в Україні, 2011-2012. Бюл. Нац. канцер-реєстру України, 14 / З. П. Федоренко, Ю.И.Михайлович, Л. О. Гулак [та ін.]. - 2013. - 120 с. 